\title{
High prevalence of enteroparasites in children from Ribeirão Preto, São Paulo, Brazil
}

\author{
Alta prevalência de enteroparasitoses em crianças de Ribeirão Preto, São Paulo, Brasil \\ Alta prevalencia de enteroparasitosis en niños de Ribeirão Preto, São Paulo, Brasil
}

\author{
Renata Elizabete Pagotti da Fonseca', Michelle Christiane Rodrigues Barbosa", Beatriz Rossetti Ferreira'"I \\ ' Universidade de São Paulo, Ribeirão Preto College of Nursing, \\ Postgraduate Program in Maternal-Infant Nursing and Public Health. Ribeirão Preto, São Paulo, Brazil. \\ "Universidade de São Paulo Ribeirão Preto School of Medicine, \\ Department of Biochemistry and Immunology. Ribeirão Preto, São Paulo, Brazil. \\ I"I Universidade de São Paulo, Ribeirão Preto College of Nursing, \\ Departament of Maternal-Infant Nursing and Public Health. Ribeirão Preto, São Paulo, Brazil.
}

How to cite this article:

Fonseca REP, Barbosa MCR, Ferreira BR. High prevalence of enteroparasites in children from Ribeirão Preto, São Paulo, Brazil. Rev Bras Enferm [Internet]. 2017;70(3):566-71. DOI: http://dx.doi.org/10.1590/0034-7167-2016-0059

Submission: 03-15-2016 Approval: 11-26-2016

\begin{abstract}
Objective: To determine the prevalence of intestinal parasites and possible associated factors. Method: Cross-sectional epidemiological study of 962 children (3-12-years) from an area within the scope of a basic health unit in Ribeirão Preto, São Paulo, Brazil. Data were collected by home interviews and three-sample stool analysis and evaluated with the chisquare and Fisher's exact tests $(p<0.05)$. Results: The prevalence of intestinal parasites was significantly high $(57.5 \%)$. Giardia lamblia was the most prevalent (50.8\%), followed by Ascaris lumbricoides (17.8\%), Entamoeba histolytica, Hymenolepis nana, Entamoeba coli and Enterobius vermiculares (5.6-7.3\%) and other parasites of lower prevalence, such as Schistosoma japonicum (1\%) and Schistosoma mansoni $(0.5 \%)$. No statistically significant associations were detected between prevalence and the risk factors analyzed. Conclusion: Since the area presents good conditions of environmental sanitation, health education programs should be implemented that emphasize hygiene procedures for the hands and for food and water to be consumed by the population.
\end{abstract}

Descriptors: Prevalence; Parasitic Diseases; Public Health Nursing; Giardia lamblia; Nurse.

\section{RESUMO}

Objetivo: Determinar a prevalência de parasitas intestinais e possíveis fatores associados. Método: Estudo epidemiológico de corte transversal, população de 962 crianças (3-12 anos) residentes em uma área de abrangência de uma Unidade Básica de Saúde na cidade de Ribeirão Preto, São Paulo, Brasil. Os dados foram coletados por meio de entrevistas domiciliares e exame de fezes (três amostras). A análise de dados aplicou testes Qui-quadrado e Fisher $(p<0,05)$. Resultados: A prevalência de parasitas foi significativamente elevada (57,5\%). Giardia lamblia foi a mais prevalente (50,8\%), seguida por Ascaris lumbricoides $(17,8 \%)$, Entamoeba histolytica, Hymenolepis nana, Entamoeba coli e Enterobius vermiculares (5,6 -7,3\%) e outros parasitas, como o Schistosoma japonicum (1\%) e Schistosoma mansoni $(0,5 \%)$. Não houve associações estatisticamente significativas entre a prevalência e os fatores de risco analisados. Conclusão: Como a área apresenta boas condições de saneamento, programas de educação em saúde devem ser implementados, enfatizando o consumo de água filtrada.

Descritores: Prevalência; Doenças Parasitárias; Saúde da Família; Giardia lamblia; Enfermeiro.

\section{RESUMEN}

Objetivo: Determinar la prevalencia y posibles asociaciones de enteroparasitosis con posibles factores asociados. Método: Estudio epidemiológico, corte transversal, muestra de 962 niños (3-12 años) en un área de cobertura de una Unidad de Salud de la Familia en Ribeirão Preto-São Paulo, Brasil. Los datos fueron recogidos mediante la aplicación de entrevistas y exámenes 
de heces con tres muestras/niño, que fueron analizados utilizando Chi-cuadrado y Fisher (0,05\%). Resultados: La prevalencia de enteroparasitosis fue alta (57,5\%). Giardia lamblia fue el parásito más frecuente (50,8\%), seguido por Ascaris lumbricoides $(17,8 \%)$, Entamoeba histolytica, H. nana, E. coli y Enterobius vermicularis $(5,6-7,3 \%)$ y otros parásitos con frecuencias más bajas. No se encontró asociación estadísticamente significativa entre prevalencia y factores de riesgo analizados. Conclusión: Aunque el área del estudio tenga buenas condiciones socioeconómicas y demográficas, existe la necesidad de implementar acciones con enfoque en la promoción de la salud de esta población.

Descriptores: Prevalencia; Enfermedades Parasitarias; Enfermería de Salud Pública; Enfermero.

\section{INTRODUCTION}

In the daily practice of health services, it is known that intestinal parasites play an important role in the daily life of families and are more frequent in lower-income regions ${ }^{(1)}$. In underdeveloped countries, prevalence rates reach $90 \%$, with a significant increase in frequency as the population's socioeconomic levels decrease and where there is lack of water and sewer treatment, trash collection and vector control ${ }^{(2-3)}$. In these countries, parasitic diseases are responsible for $25 \%$ of illnesses. To reduce these rates, it is necessary to invest in strategies to improve the population's socioeconomic level. In the case of Brazil, programs such as the Family Health and Fome Zero (Zero Hunger) have been shown to be good starting points for improving family health care $^{(4)}$.

However, parasitic diseases are still prevalent in Brazil. Due to the size and diversity of its geographical regions, there is great variation among states and municipalities. In the state of São Paulo, one study found that the prevalence of intestinal parasites in children 0 to 12 years old ranged from $11.5 \%$ to $30.32 \%(2,5)$. A study in municipal day care centers in Niterói, Rio de Janeiro ${ }^{(6)}$ found that the prevalence of parasites was $61.3 \%$, with a predominance of Giardia lamblia (G.lamblia). In Minas Gerais (MG), a study found that the prevalence of intestinal parasites was $34.6 \%(n=1338)$ in urban slums ${ }^{(7)}$.

Children still make up part of the most vulnerable group, because their hygiene habits tend to be inadequate and some are born with poorly functioning immune systems ${ }^{(8)}$. In most studies, the prevalence of parasitic diseases was greater among children 3 to 12 years old, decreasing with age.

Regarding prevalence of intestinal parasites in the region of Ribeirão Preto, São Paulo, few publications were found, and none were conducted in the area proposed by the present study. The prevalence of intestinal parasites among preschool children in a general pediatric outpatient clinic in Ribeirão Preto-SP was $24.5 \%$ ( $n=155$ children); of these, 50\% had giardiasis ${ }^{(9)}$.

Nurses, as a key element in primary care of communities, must produce knowledge to establish an evidence base to help promote community health. The current study investigated the prevalence of intestinal parasites among children 3 to 12 years old in an area within the scope of a basic health unit (BHU) in the municipality of Ribeirão Preto, São Paulo, Brazil. It also explored possible associations between intestinal parasite infection and socioeconomic and demographic profiles of families and the population's health conditions and behavior.

\section{METHOD}

\section{Ethical aspects}

The study was conducted in accordance with the guiding principles of Resolution 466/2012 of the National Council of the Brazilian Ministry of Health. The project was approved by the Ethics Committee of the University of São Paulo at the Ribeirão Preto College of Nursing. All adults responsible for the children who were invited to participate agreed and signed informed consent forms.

\section{Selection of sample and location and period of study}

This was a cross-sectional epidemiological study to explore socioeconomic and demographic factors, and health conditions and behavior of 962 children between the ages of 3 and 12 in an area within the scope of a basic health unit in the municipality of Ribeirão Preto-SP, to determine the prevalence of intestinal parasites and possible associations and risk factors. The city is located $360 \mathrm{~km}$ northeast of the state capital and has an estimated population of 649,556 . The region stands out for its significant agribusiness activities and service sector, with the $30^{\text {th }}$ highest GDP in Bra$\mathrm{zil}^{(10)}$. The data were collected between October 2012 and May 2013.

\section{Population and sample}

Sample size was calculated by dividing the studied population into three age groups (3-6, 7-9 and 10-12). Individuals from each age group were then selected at random, totaling 576 children. There was no replacement of losses of samples.

\section{Study protocol}

After agreeing to participate in the study, the adults response for the children answered a structured questionnaire that investigated the educational level of the head of the household; amount and source of family income; characteristics of the home; and the children's health conditions and behavior. Stool samples from the children were collected using the TF Test kit (Three Fecal Test, Immunoassay Ind. Com. Ltda., São Paulo, Brazil), which analyzes three samples of feces collected on alternate days and has a $96.8 \%$ sensitivity rate $^{(3)}$. Stool samples were examined in duplicate to identify the parasites by optical microscopy (40 to 100x obj.). Children who tested positive for intestinal parasites were referred to the $\mathrm{BHU}$ physician to receive proper treatment. 


\section{Data analysis}

The prevalence ratio was determined with a 95\% confidence interval. The chi-square and Fisher's exact tests were used to determine the significance of associations between risk factors and children's socioeconomic and health conditions. The Statistical Package for the Social Sciences, version 10.0 (SPSS Inc., Chicago, IL, USA) and Ri386 3.0.0 software (public domain) were used for these calculations.

\section{RESULTS}

Of the adults responsible for the 576 children composing the sample, $40(7 \%)$ refused to participate in the study, the main reason being that they had private health insurance and did not make use of the BHU. Fifty-seven (9.9\%) adults moved during the period of the study and 17 (3\%) could not be found, even after four home visits at different times of the day. Therefore, interviews were conducted with 387 adults who were responsible for 462 children (for some families, more than one child was selected per adult). Of the 462 children, stool samples were delivered and examined for only 233 (50.4\%).

Data analysis was divided as follows: the researchers analyzed the socioeconomic and demographic factors and possible factors associated with intestinal parasites in the homes of 387 families (Table 1); the health conditions of 462 children; and the prevalence of intestinal parasites and its association with the health conditions and behavior of 233 children (Figure 1).

The income of most families (42.9\%) ranged from $\mathrm{R} \$ 679.00$ to $\mathrm{R} \$ 1,358.00$ (US\$174.1 to US\$348.2). Most heads of households had jobs requiring only elementary occupations $(70.5 \%)$; only $5(1.3 \%)$ had jobs that required post-secondary education. Those who received pensions from the National Institute of Social Security (INSS) or were retired or unemployed were considered "economically inactive," and this category represented $11.9 \%$ of the heads of household. Most had completed elementary school $(31.3 \%), 1.6 \%$ were illiterate, and only $4.4 \%$ had post-secondary degrees (Table 1).

Most houses $(81.7 \%)$ were composed of bricks and plaster; others were made only of bricks (18.3\%). Most families (67.2\%) drank tap water; only $32.8 \%$ drank filtered water (Table 1). Nearly all families used water from the public supply $(99.4 \%)$ and municipal sewage system $(97.7 \%)$. Only one family $(0.3 \%)$ did not have electricity at home $100 \%$ of the families had access to trash collection services (data not showed on table).

Considering the variable "How food is washed," $49.9 \%$ of the families washed fruit and vegetables only with water (Table 1). Of those who used disinfectants, only $34 \%$ used sodium hypochlorite (bleach); $66 \%$ used a vinegar solution.

Regarding the children's health conditions, according to the adults, $36.4 \%$ of the children had had some type of health problem in the last month. Of these, $66 \%$ were possibly related to parasitic infections, in accordance with the symptoms described, such as cough, diarrhea, weight loss, abdominal pain, anal itching and skin rashes.

Most importantly, our study showed a prevalence of $57.5 \%$ of children who tested positive for intestinal parasites. G. lamblia was the most prevalent $(50.8 \%)$, followed by Ascaris lumbricoides (A. lumbricoides) with $17.8 \%$, Entamoeba coli (E.coli) with $7.8 \%$ and Enterobius vermiculares (E. vermiculares) with $7.3 \%$. Additionally, Entamoeba histolytica (E. histolytica) and Hymonolepis nana $(H$. nana) presented similar prevalence rates $(5.6 \%$ and $4.2 \%$, respectively). One child $(0.5 \%)$ was infected with Schistosoma mansoni (S. mansoni) and two children (1\%) with Schistosoma japonicum (S. japonicum), a uncommon parasites in Brazil. Other intestinal parasites were also found, although at much lower frequencies (Figure 1).
A.

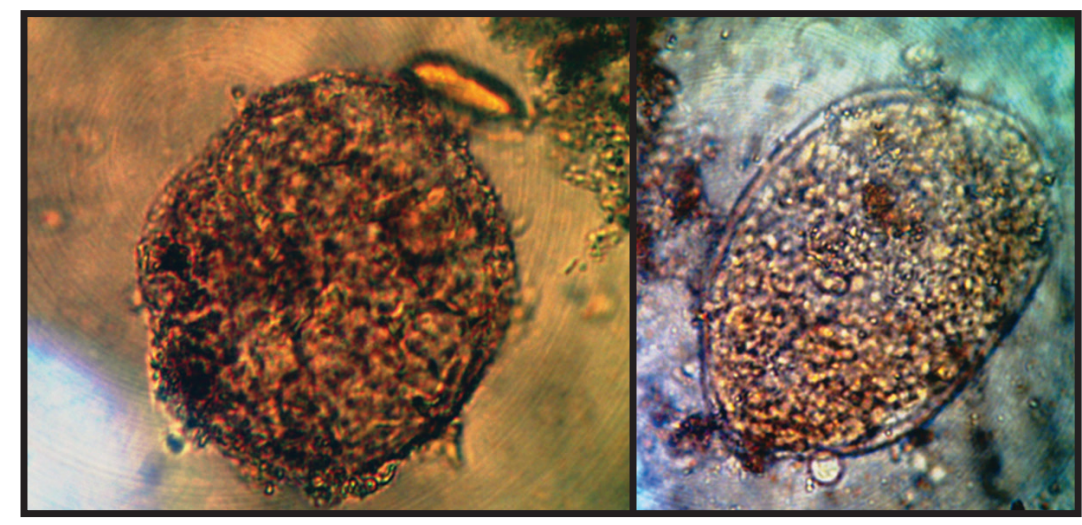

B.

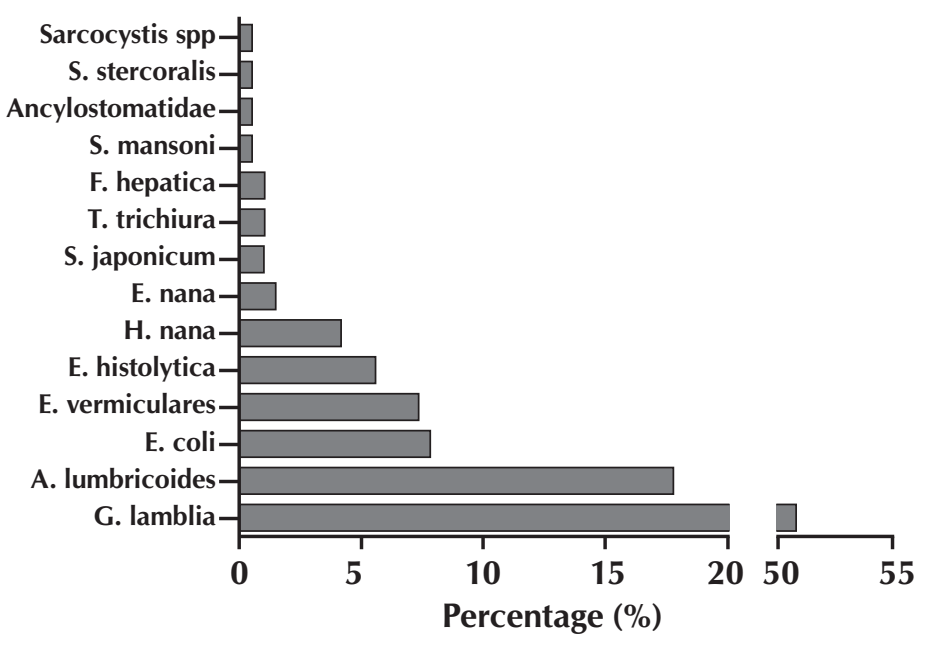

Figure 1 - (A) Eggs of Schistosoma japonicum found in a child's stool sample (40x Obj.); (B) Intestinal parasites found among children $(n=233)$ in an area of the municipality of Ribeirão Preto, São Paulo, Brazil, 2013 
Table 1 - Socioeconomic and living conditions $(n=387)$ of study participants, Ribeirão Preto, São Paulo, Brazil, 2013

\begin{tabular}{|c|c|c|}
\hline \multirow{2}{*}{ Variables } & \multicolumn{2}{|c|}{ Heads of household } \\
\hline & $\mathbf{n}$ & $\%$ \\
\hline \multicolumn{3}{|l|}{ Family income $\left(\mathrm{MW}^{\mathrm{a}}\right)$} \\
\hline$\leq 1$ & 37 & 9.6 \\
\hline $1-2$ & 166 & 42.9 \\
\hline $2-3.5$ & 104 & 26.9 \\
\hline $3.5-5$ & 43 & 11.1 \\
\hline$\geq 5$ & 21 & 5.4 \\
\hline Not reported & 16 & 4.1 \\
\hline \multicolumn{3}{|l|}{ Occupation of head of family } \\
\hline Basic level & 273 & 70.5 \\
\hline Technical level & 54 & 14.0 \\
\hline Professional level & 5 & 1.3 \\
\hline Inactive ${ }^{b}$ & 46 & 11.9 \\
\hline Others & 9 & 2.3 \\
\hline \multicolumn{3}{|l|}{ Educational level of head of family } \\
\hline Illiterate & 6 & 1.6 \\
\hline Primary & 43 & 11.1 \\
\hline Elementary & 121 & 31.3 \\
\hline Secondary & 116 & 30.0 \\
\hline Post-secondary & 17 & 4.4 \\
\hline Not reported & 84 & 21.6 \\
\hline \multicolumn{3}{|l|}{ Type of house } \\
\hline Brick & 71 & 18.3 \\
\hline Brick and plaster & 316 & 81.7 \\
\hline \multicolumn{3}{|l|}{ Type of water consumption } \\
\hline Tap & 260 & 67.2 \\
\hline Filtered & 127 & 32.8 \\
\hline \multicolumn{3}{|l|}{ Bathroom location } \\
\hline Adjacent to kitchen & 116 & 30.0 \\
\hline Away from the kitchen & 267 & 69.0 \\
\hline Other & 4 & 1.0 \\
\hline \multicolumn{3}{|l|}{ How food is washed? } \\
\hline Only with water & 193 & 49.9 \\
\hline With water and soap or disinfectant solution & 194 & 50.1 \\
\hline
\end{tabular}

Note: aMW - Minimum wage, $R \$ 678.00$ in January 2013; bPeople who received pensions from the National Institute of Social Security, or were retired or unemployed.

Regarding the prevalence of multiple infections, most infected children tested positive for one parasite $(64.9 \%)$; infection by multiple parasites was observed in $35.1 \%$ of the individuals.

Next, data were analyzed to investigate possible associations between the prevalence of intestinal parasites and risk factors related to the children's socioeconomic and health conditions. This analysis did not result in any statistically significant associations. For example, the mother's education level, family income and home water consumption presented p-values of $0.675,0.116$ and 0.358 , respectively.

\section{DISCUSSION}

The present study determined the prevalence of intestinal parasites in a sample of children between 3 and 12 years old in an area within the scope of a basic health unit in the municipality of Ribeirão Preto, São Paulo, Brazil. The results demonstrated a high prevalence of intestinal parasites among the population and the presence of risk factors for parasitic infection. However, no statistically significant associations were found. These findings reinforce the importance of implementing actions focused on health promotion to reduce intestinal parasitic infections in this population. It should be noted that nurses have an important role in social determinants of health, such as education ${ }^{(11)}$, and are inserted in a health care model that privileges health education ${ }^{(12)}$.

The prevalence of intestinal parasites in the study was $57.5 \%$. Other municipalities in the state of São Paulo have also shown high rates of parasitic infections among children. A study by Araujo Filho et al. ${ }^{(2)}$ determined the prevalence of intestinal parasites among children who lived in a slum $(60.7 \%)$ and children who studied in a private school in Osasco, São Paulo (5.9\%). Another study by Komagome et al. ${ }^{(13)}$ in Itambé, São Paulo found a $34.5 \%$ positivity rate for parasites in samples of 127 children and 18 day care staff members. The prevalence found in the present study (57.5\%) is similar to that of other regions in Brazil; in the North and Northeast regions, studies have found prevalence rates among children ranging from $41.7 \%$ to $79.3 \%{ }^{(14-15)}$.

G. lamblia was the most prevalent parasite in the examined population $(50.8 \%)$, a finding that corroborates those of other coproparasitological studies conducted in Brazil(1,5-7,13,16). The transmission of $G$. lamblia occurs primarily by contaminated water and unclean hands. Thus, it is essential to identify possible contamination focal points responsible for maintenance of protozoa in the environment ${ }^{(1)}$.

In the studied area, $67.2 \%$ of the population consumed tap water (not filtered). The water supply for the population of Ribeirão Preto comes from an underground reservoir called Aquífero Guarani, whose quality control is ensured by a municipal body ${ }^{(10)}$. However, it is important to emphasize the issue of inadequate storage of water for consumption, which can favor the growth and maintenance of parasites. One study showed that $54.5 \%$ of water samples from reservoirs in a community (barrels) located on the outskirts of the municipality of Ribeirão Preto-SP contained not only fecal coliforms, but also intestinal parasites such as $E$. vermiculares and $A$. lumbricoides ${ }^{(17)}$.

Another possible explanation for the high prevalence of G. lamblia in this population is that $12.3 \%$ of the children washed their hands only with water. Several studies have shown that washing the hands with water alone does not eliminate contamination by eggs and cysts of many parasites. One example is the G. lamblia cyst, which can survive several months in room temperature water ${ }^{(18)}$. It is worth noting that the adults frequently reported that the children only washed their hands on request.

The second most prevalent parasite in the study was $A$. lumbricoides $(17.8 \%)$. This is the most frequent parasite in the world, with an estimated one million people infected ${ }^{(19)}$. In general, Brazil presents environmental conditions that are favorable 
to the dissemination of soil-transmitted helminthiases, due to the tropical climate (hot and humid) of most of its territory.

One finding that deserves special attention was that one child $(0.5 \%)$ tested positive for S. mansoni. Ribeirão PretoSP is not considered an area where schistosomiasis is endemic. Therefore, thus another interview was carried out with the affected family and it was verified that the infected child frequently visited family members who lived in the state of Minas Gerais, which is an area where this particular parasite is endemic ${ }^{(4,20)}$. Indeed, the literature has shown few registered cases of schistosomiasis in the state of São Paulo; most cases are associated with the Northeast region of $\mathrm{Brazil}^{(20)}$.

According to the Brazilian Ministry of Health, schistosomiasis affects 2.5 to 6 million individuals in Brazil. There are records of high prevalence rates of this parasitic disease in the states of Alagoas, Pernambuco, Sergipe, Bahia, Paraíba, Minas Gerais and Espírito Santo. Contamination focal points are also found also in Pará, Piauí, Goiás, the Federal District, Rio de Janeiro, São Paulo, Paraná, Santa Catarina and Rio Grande do Sul (20). One study conducted with 913 individuals in Guarulhos, São Paulo, detected a prevalence rate of $0.2 \%$ for $S$. mansoni ${ }^{(21)}$.

Another interesting result was that two children tested positive for S. japonicum. Japanese schistosomiasis was introduced into Brazil by Asian immigrants. However, it did not find good conditions for its intermediary host, a snail of the genus Oncomelania, which did not adapt well to the Brazilian climate ${ }^{(22)}$.

The presence of Japanese schistosomiasis cases in Brazil was described long ago (1940) by Bandeira and Pires ${ }^{(23)}$; no recent studies were found in the literature. It is possible that the two cases identified are allochthonous, because the area of coverage of the study contained immigrants from areas where this parasite is endemic.

The high frequency of multiple parasitic infections (35.1\%) has also been described in other studies conducted in Bra$\mathrm{zil}^{(6,13,16)}$. This is a particularly worrying situation among lowerincome populations, because it can delay physical growth and cause learning disabilities, especially in school-age children ${ }^{(18)}$.

One of the strengths of the present study was that it utilized three stool samples from each child (collected on alternate days) for analysis; this method reduces the chance of underestimating the prevalence of parasitic infection ${ }^{(3)}$.

\section{Limitations of the study}

No statistically significant associations were found between the prevalence of intestinal parasites and the risk factors analyzed. This could be due to sample loss related to non-delivery of stool samples for the parasite analysis, which decreased the sample size.

Contributions to the field of nursing, health or public policy

The present study contributes to nursing, considering the high prevalence of parasitic diseases and the importance of nurses in the development of health education activities. Nurses, as a key element in primary care in communities, must produce knowledge to establish an evidence base to help promote community health.

\section{CONCLUSION}

Overall, the findings of the present study indicate a high prevalence of parasitic diseases in Ribeirão Preto-SP, a municipality that composes a region of relevance to agriculture and agribusiness in the state of São Paulo, in addition to being prominent center in the area of health and education. Furthermore, the study identified children infected with S. japonicum, an uncommon parasite in Brazil. Thus, the study suggests that parasitic diseases deserve more attention, and efforts must be made to reduce these prevalence rates in order to offer improved quality of life to the population. Since the area presents good conditions of environmental sanitation, health education programs should be implemented that emphasize hygiene procedures for the hands and for food and water to be consumed by the population.

\section{ACKNOWLEDGEMENTS}

We would like to thank the basic health unit staff for their assistance.

\section{REFERENCES}

1. Lima Jr OA, Kaiser J, Castiti R. High occurrence of giardiasis in children living on a 'landless farm workers' settlement in Araras, São Paulo, Brazil. Rev Inst Med Trop [Internet]. 2013 [cited 2016 Feb 17];55(3):185-8. Available from: http://www.scielo.br/pdf/ rimtsp/v55n3/0036-4665-rimtsp-55-03-185.pdf

2. Araujo Filho HB, Carmo-Rodrigues MS, Mello CS, Melli LCFL, Tahan S, Morais MB. Intestinal parasitoses are associated with lower values of weight and height in school-aged children from low socioeconomic level. Rev Paul Pediatr [Internet]. 2011 [cited 2016 Feb 17];29(4):521-8. Available from: http://www.scielo.br/pdf/rpp/v29n4/en_09.pdf

3. Carvalho GLX, Moreira LE, Pena JL, Marinho CM, Bahia MT, Machado-Coelho GLL. A comparative study of the TF-Test ${ }^{\circledR}$, Kato-Katz, Hoffman-Pons-Janer, Willis and Baermann-Moraes coprologic methods for the detection of human parasitosis. Mem. Inst. Oswaldo Cruz [Internet]. 2012 [cited 2016 Feb 17];107 (1):80-4. Available from: http://www.scielo.br/pdf/mioc/v107n1/11.pdf

4. World Health Organization. Elimination of schistosomiasis from low-transmission areas: report of a WHO informal consultation, Salvador, Bahia, Brazil, 18-19 August 2008. Geneva: World Health Organization [Internet]. 2009 [cited 2016 Feb 17]. Available from: http://whqlibdoc.who.int/hq/2009/WHO_HTM_NTD_PCT_2009.2_eng.pdf

5. Belloto MVT, Santos Jr JE, Macedo EA, Ponce A, Galisteu, KJ, Castro E, et al. Enteroparasitoses numa população de escolares da rede 
pública de ensino do Município de Mirassol, São Paulo, Brasil. Rev Pan-Amaz Saúde [Internet]. 2011 [cited 2016 Feb 17];2(1):37-44. Available from: http://scielo.iec.pa.gov.br/pdf/rpas/v2n1/en_v2n1a04.pdf

6. Uchoa CMA, Albuquerque MC, Carvalho FM, Falcão AO, Silva P, Bastos OMP. Parasitismo intestinal em crianças e funcionários de creches comunitárias na cidade de Niterói - RJ, Brasil. Rev Patol Trop [Internet]. 2009 [cited 2016 Feb 17];38(4):267-78. Available from: https://portais.ufg.br/up/63/o/2009_38_4_267_278.pdf

7. Gil FF, Busatti HGNO, Cruz VL, Santos JFG, Gomes MA. High prevalence of enteroparasitosis in urban slums of Belo Horizonte-Brazil. Presence of enteroparasites as a risk factor in the family group. Pathog Glob Health [Internet]. 2013 [cited 2016 Feb 17];107(6):320-4. Available from: http://www.ncbi.nlm.nih.gov/pmc/articles/PMC4001612/.

8. USA. National Institutes of Health. Understanding the immune system. How it works .U.S. Department of Health and Human Services. National Institutes of Health National Institute of Allergy and Infectious Diseases, National Institutes of Health Publication No. 07-5423 [Internet]; 2007 [cited 2016 Feb 17]. Available from: http://www.imgt.org/IMGTeducation/Tutorials/ImmuneSystem/ UK/the_immune_system.pdf

9. Ferraz IS, Daneluzzi JC, Vannucchi H, Jordão Jr AA, Ricco RG, Ciampo LAD et al. Estudo da prevalência de parasitoses intestinais e de sua influência na deficiência de vitamina A em pré-escolares vivendo na zona urbana. VLIII Reunião Anual da Sociedade LatinoAmericana de Investigação Pediátrica; 2005; Ribeirão Preto, São Paulo, Brasil; 2005. p. 32-32.

10. Prefeitura Municipal de Ribeirão Preto. [Internet]. 2016 [cited 2016 Feb 17]. Available from: http://www.ribeiraopreto.sp.gov.br/ principal.php\#

11. Shamian J. The role of nursing in health care. Rev Bras Enferm [Internet]. 2014 [cited 2016 Feb 17];67(6):867-8. Available from: http:// www.scielo.br/pdf/reben/v67n6/0034-7167-reben-67-06-0867.pdf

12. Busato MA, Dondoni DZ, Rinaldi ALS, Ferraz L. Parasitoses intestinais: o que a comunidade sabe sobre esse tema? RBMFC [Internet]. 2015 [cited 2016 Feb 17];10(34):1-6. Available from: https://rbmfc.org.br/rbmfc/article/view/922

13. Komagome SH, Romagnoli MPM, Previdelli ITS, Falavigna DLM, Dias MLGG, Gomes ML. Fatores de risco para infecção parasitária intestinal em crianças e funcionários de creche. Cienc Cuid Saúde [Internet]. 2007 [cited 2016 Feb 17];6(2):442-7. Available from: http://eduem.uem.br/ojs/index.php/CiencCuidSaude/article/viewFile/5354/3391

14. Gomes PDMF, Nunes VLBN, Knechtel DS, Brilhante AF. Enteroparasitos em escolares do distrito águas do Miranda, município de Bonito, Mato Grosso do Sul. Rev Patol Trop [Internet]. 2010 [cited 2016 Feb 17];39 (4):299-307. Available from: https://www.revistas. ufg.br/index.php?journal $=$ iptsp\&page $=$ article \&op $=$ view\&path $\% 5 B \% 5 \mathrm{D}=13065 \&$ path $\% 5 \mathrm{~B} \% 5 \mathrm{D}=8511$

15. Miranda GC, Dattoli VCC, Dias-Lima A. Enteroparasitos e condições socioeconômicas e sanitárias em uma comunidade quilombola do semiárido baiano. Rev Patol Trop [Internet]. 2010 [cited 2016 Feb 17];39(1):48-55. Available from: http://www.revistas.ufg.br/index. php/iptsp/article/view/9498

16. Gonçalves ALR, Belizario, TL, Pimentel JB, Penatti MPA, Pedroso, RS. Prevalence of intestinal parasites in preschool children in the region of Uberlândia, State of Minas Gerais, Brazil. Rev Soc Bras Med Trop [Internet]. 2011 [cited 2016 Feb 17];44(2):191-3. Available from: http://www.scielo.br/pdf/rsbmt/v44n2/aop21-11.pdf

17. Julião FC. Água para consumo humano e saúde: ainda uma iniquidade em área periférica do município de Ribeirão Preto - SP, [Tese]. Escola de Enfermagem de Ribeirão Preto, Universidade de São Paulo; 2003.

18. USA. Centers for disease control and prevention. Parasites. Centers for disease control and prevention; [Internet]. 2016 [cited 2016 Feb 17]. Available from: http://www.cdc.gov/parasites/az/index.html

19. World Health Organizations. WHO plans major scale-up of interventions for soil-transmitted helminthiases (intestinal worms). Geneva [Internet]. 2012 [cited 2016 Feb 17]. Available from: http://www.who.int/neglected_diseases/STH_scale_up_2012/en/.

20. Brasil. Ministério da Saúde. Plano Integrado de ações estratégicas de eliminação da hanseníase, filariose, esquistossomose e oncocercose como problema de saúde pública, tracoma como causa de cegueira e controle de geohelmintíases. Brasília: Ministério da Saúde [Internet]. 2012 [cited 2016 Feb 17]. Available from: http://bvsms.saude.gov.br/bvs/publicacoes/plano_integrado_acoes_estrategicas_hanseniase.pdf

21. Chieffi PP, Waldman EA, Dias RMDS, Torres DMGAV, Chimara R, Mizumoto LC et al. Enteroparasitoses no município de Guarulhos, SP, Brasil. Prevalência de infecções em escolares residentes no bairro de Taboão, em junho de 1984. Rev Inst Adolfo Lutz 1988;48 $(1 / 2): 75-80$.

22. Melo AL, Coelho PMZ. Shistosoma mansoni e a doença. In: Neves DP et al. Parasitologia Humana. 11 ed. São Paulo: Atheneu; 2005. p. 193-212.

23. Bandeira JAT, Pires AC. O primeiro (?) caso de doença de Katayama no Brasil. Rev Res Med. 1940;7(1):6-7. 